\title{
Acid-Free Synthesis of Mesoporous Silica Using Triblock Copolymer as Template with the Aid of Salt and Alcohol
}

\author{
Shih-Yuan Chen and Soofin Cheng* \\ Department of Chemistry, National Taiwan University, Taipei 106, Taiwan
}

Received January 25, 2007. Revised Manuscript Received March 24, 2007

\begin{abstract}
Under acid-free conditions using tetraethyl orthosilicate (TEOS) as the silica source and triblock copolymer P123 as the template, mesoporous silica materials of either ultra-large mesoporous cellular foam (MCF) or two-dimensional (2D)-hexagonal $p 6 \mathrm{~mm}$ pore arrangement were synthesized with the aid of salt and alcohol. The pore structure was varied with the concentrations of $\mathrm{P} 123$ and $\mathrm{NaCl}$ and the presence of alcohol in the synthesis solution. The porous network of the resulting MCF structure obtained in the aqueous solutions containing TEOS, $\mathrm{P} 123$, and $\mathrm{NaCl}$ was changed from closed window cell to open window cell when the concentrations of $\mathrm{P} 123$ and $\mathrm{NaCl}$ were increased. On the other hand, when a proper amount of ethanol was added as cosolvent, mesoporous silica with 2D-hexagonal pore arrangement similar to that of SBA-15 and MSU-H was obtained. The resultant materials possessed high surface area $\left(626-896 \mathrm{~m}^{2} / \mathrm{g}\right)$, mesopores $(6.3-6.6 \mathrm{~nm}$ in diameter) of reasonable pore size distribution $(2.5-3.0$ $\mathrm{nm})$, and large porosity $\left(0.91-1.13 \mathrm{~cm}^{3} / \mathrm{g}\right)$. On the basis of the ${ }^{29} \mathrm{Si}$ magic angle spinning NMR spectra, the mesoporous materials synthesized under acid-free conditions have better cross-linked silica framework than those prepared in an acidic environment such as SBA-15. The pore ordering was retained even after boiling the material in water for $72 \mathrm{~h}$. Moreover, the pore size distribution was narrowed down to 1.0$1.7 \mathrm{~nm}$, attributed to the re-organization of the silica framework during the hydrothermal treatment.
\end{abstract}

\section{Introduction}

Mesoporous materials have been widely studied since the first report by the researchers at Mobil, ${ }^{1}$ because of their potential applications in sorption, separation, catalysis, nanocasting, and electro-optical devices. ${ }^{2-4}$ Generally, the materials of ordered mesopores are synthesized by selfassembly of the surfactant-type templates and inorganic precursors through electrostatic forces or hydrogen bonding. ${ }^{1,5,6}$ Materials of relatively large pores have been obtained

* Corresponding author. Fax: +886-2-23636359. E-mail: chem1031@ ntu.edu.tw.

(1) (a) Kresge, C. T.; Leonowicz, M. E.; Roth, W. J.; Vartuli, J. C.; Beck, J. S. Nature 1992, 359, 710. (b) Beck, J. S.; Vartuli, J. C.; Roth, W. J.; Leonowicz, M. E.; Kresge, C. T.; Schmitt, K. D.; Chu, C. T.-W.; Olson, D. H.; Sheppard, E. W.; McCullen, S. B.; Higgins, J. B.; Schlenker, J. L. J. Am. Chem. Soc. 1992, 114, 10834. (c) Lu, A.-H.; Schuth, F. Adv. Mater. 2006, 18, 1793.

(2) (a) Feng, X.; Fryxell, G. E.; Wang, L. Q.; Kim, A. Y.; Liu, J.; Kemner, K. M. Science 1997, 276, 92. (b) Brown, J.; Mercier, L.; Pinnavaia, T. J. Chem. Commun. 1999, 69.

(3) (a) Corma, A. Chem. Rev. 1997, 97, 237. (b) Wang, X.; Chen, C. C.; Chen, S. Y.; Mou, Y.; Cheng, S. Appl. Catal. A 2005, 281, 47. (c) Crudden, C. M.; Sateesh, M.; Lewis, R. J. Am. Chem. Soc. 2005, 127, 10045.

(4) (a) Baskaran, S.; Liu, J.; Domansky, K.; Kohler, N.; Li, X.; Coyle, C.; Fryxell, G. E.; Thevuthasan, S.; Williford, R. E. Adv. Mater. 2000 , 12, 291. (b) Wang, Y.; Yang, C. M.; Schmidt, W.; Spliethoff, B.; Bill, E.; Schüth, F. Adv. Mater. 2005, 17, 53. (c) Yang, P. D.; Wirnsberger, G.; Huang, H. C.; Cordero, S. R.; McGehee, M. D.; Scott, B.; Deng, T.; Whitesides, G. M.; Chmelka, B. F.; Buratto, S. K.; Stucky, G. D. Science 2000, 287, 465.

(5) Tanev, P. T.; Pinnavaia, T. J. Science 1995, 267, 865.

(6) (a) Zhao, D.; Feng, J.; Huo, Q.; Melosh, N.; Fredrickson, G. H.; Chmelka, B. F.; Stucky, G. D. Science 1998, 179, 548. (b) Zhso, D.; Huo, Q.; Feng, J.; Chmelka, B. F.; Stucky, G. D. J. Am. Soc. Chem. 1998, 120, 6024. (c) Melosh, N. A.; Davidson, P.; Chmelka, B. F. J. Am. Chem. Soc. 2000, 122, 823. (d) Yang,C. M.; Zibrowius, B.; Schmidt, W.; Schuth, F. Chem. Mater. 2004, 16, 2918. by using amphiphilic triblock copolymers as the poredirecting agents under strong acidic condition. Among them, two-dimensional (2D)-hexagonal SBA-15 synthesized with Pluronic P123 $\left(\mathrm{EO}_{20} \mathrm{PO}_{70} \mathrm{EO}_{20}\right)$ as the pore directing agent has received great attention because of its relatively large pores and high hydrothermal stability. ${ }^{6-8}$ For the purpose of further expanding the pore diameter, swelling agents such as trimethylbenzene (TMB) which dissolves in the hydrophobic core of P123 micelles are usually added into the synthesis mixture. When the TMB/P123 mass ratio was greater than 0.3 , ultra-large mesoporous cellular foam (designated as MCF) was obtained, ${ }^{7 \mathrm{c}}$ which could also be made using hard templates such as polymer nanospheres. ${ }^{8}$ Both SBA-15 and MCF materials have shown higher adsorption capacities and faster adsorption rates toward large molecules, in comparison to those of the M41S family. ${ }^{7 e, f}$ However, the synthesis conditions for SBA-15 and MCF are usually in strong acids and environmentally unfriendly. The mineral acids are considered to play a key role in assembly of the surfactant and silica precursor through a $\mathrm{N}^{0} \mathrm{H}^{+} \mathrm{X}^{-} \mathrm{S}^{+}$ type interaction, ${ }^{6}$ where $\mathrm{N}^{0}$ is the neutral surfactant, $\mathrm{H}^{+}$is the proton, $\mathrm{X}^{-}$is the counteranion, and $\mathrm{S}^{+}$is the protonated silicate species. Although several reports have shown that

(7) (a) Lukens, W. W.; Schmidt-Winkel, P.; Zhao, D.; Feng, J.; Stucky, G. D. Langmuir 1999, 15, 5403. (b) Lukens, W. W.; Yang, P.; Stucky, G. D. Chem. Mater. 2001, 13, 28. (c) Lettow, J. S.; Han, Y. J.; Schmidt-Winkel, P.; Yang, P.; Zhao, D.; Stucky, G. D.; Ying, J. Y. Langmuir 2000, 16, 8291. (d) Han, Y.-J.; Watson, J. T.; Stucky, G. D.; Butler, A. J. Mol. Catal. B: Enzym. 2002, 17, 1. (e) Han, Y.; Lee, S. S.; Ying, J. Y. Chem. Mater. 2006, 18, 643. (f) SchmidtWinkel, P.; Lukens, Jr., W. W.; Yang, P.; Margolese, D. I.; Lettow, J. S.; Ying, J. Y.; Stucky, G. D. Chem. Mater. 2000, 12, 686.

(8) Fan, J.; Yu, C.; Wang, L.; Tu, B.; Zhao, D.; Sakamoto, Y.; Terasaki, O. J. Am. Chem. Soc. 2001, 123, 12113. 
the final synthesis gels of SBA-15 can be adjusted to near neutral by neutralizing the acidified surfactant solutions with weak bases or sodium silicate, the synthesis procedures have been very complicated and uncontrollable. ${ }^{9-12}$

Our laboratory has developed a method to synthesize wellordered mesoporous SBA-15 materials incorporated with large amounts of tetravalent cations such as $\mathrm{Zr}^{4+}$ and $\mathrm{Sn}^{4+}$ without the addition of hazardous mineral acids. ${ }^{13}$ The acidity generated from the hydrolysis of the metal salts in water was considered high enough to catalyze the tetraethyl orthosilicate (TEOS) hydrolysis. In addition, the long-range ordering of the mesopores in the materials was significantly improved by the addition of mineral salts such as $\mathrm{NaCl}, \mathrm{KCl}$, $\mathrm{K}_{2}\left(\mathrm{SO}_{4}\right)$, and NaI. It has been suggested that salts can decrease the critical micelle temperature (CMT) of the surfactants, increase the ionic strength of synthesis solutions, and thus facilitate the self-assembly of the micelles and inorganic presursors. ${ }^{13-19} \mathrm{We}$ have shown recently in a short communication the success of preparing pure siliceous mesoporous materials using triblock copolymer as poredirecting agent without adding hazardous mineral acids. ${ }^{20}$ Herein a detailed study on the preparation condition of the mesostructured silica materials under acid-free condition using triblock copolymer as template was presented. The materials were characterized with various techniques, including small-angle X-ray diffraction (XRD), thermogravimetric (TG) analysis, elemental analysis, nitrogen sorption isotherm, pore size analysis, solid state ${ }^{29} \mathrm{Si}$ magic angle spinning (MAS) NMR, and scanning and transmission electron microscopies (SEM and TEM). Moreover, the resultant mesostructured silica materials were found to have high hydrothermal stability because of the better cross-linking of the silica framework.

\section{Experimental Methods}

Synthesis. No mineral acids and swelling agents were used in the synthesis procedures. The reactants in the synthesis gel were amphiphilic triblock copolymer (P123) as pore-directing agent, TEOS as the silica source, $\mathrm{NaCl}$ salt, and sometimes the alcohol

(9) (a) Kim, S.-S.; Pauly, T. R.; Pinnavaia, T. J. Chem. Commun. 2000, 1661. (b) Kim, S. S.; Karkamkar, A.; Pinnavaia, T. J.; Kruk, M.; Jaronec, M. J. Phys. Chem. B 2001, 105, 7663.

(10) Kim, J. M.; Han, Y. J.; Chmelka, B. F.; Stucky, G. D. Chem. Commun. 2000, 2437.

(11) Sierra, L.; Lopez, B.; Gil, H.; Guth, J. L. Adv. Mater. 1999, 11, 307.

(12) Song, H.; Rioux, R. M.; Hoefelmeyer, J. D.; Komor, R.; Niesz, K.; Grass, M.; Yang, P.; Somorjai. G. A. J. Am. Chem. Soc. 2006, 128, 3027.

(13) (a) Chen, S. Y.; Jang, L. Y.; Cheng, S. Chem. Mater. 2004, 16, 4174. (b) Chen, S. Y.; Cheng, S.; Chung, W. T.; Lee, J. J.; Chiang, Y. P.; Tang, C. Y.; Lin, C. Y. Stud. Surf. Sci. Catal. 2006, 162, 369.

(14) (a) Yu, C.; Tian, B.; Fan, J.; Stucky, G. D.; Zhao, D. J. Am. Chem. Soc. 2002, 124, 4556. (b) Yu, C.; Fan, J.; Tian, B.; Zhao, D.; Stucky, G. D. Adv. Mater. 2002, 14, 1742.

(15) Flodstrom, K.; Alfredsson, V.; Kallrot, N. J. Am. Chem. Soc. 2003 , 125,4402

(16) Guo, W.; Park, J. Y.; Oh, M. O.; Jeong, H. W.; Cho, W. J.; Kim, I.; Ha, C. S. Chem. Mater. 2003, 15, 2295.

(17) Wang, Y. Q.; Yang, C.-M.; Zibrowius, B.; Spliethoff, B.; Linden, M.; Schuth, F. Chem. Mater. 2003, 15, 5029.

(18) Karkamkar, A.; Kim, S. S.; Pinnavaia, T. J. Chem. Mater. 2003, 15, 11

(19) (a) Das, D.; Tsai, C. M.; Cheng, S. Chem. Commun. 1999, 473. (b) Chen, S. Y.; Jang, L. Y.; Cheng, S. J. Phys. Chem. B 2006, 110, 11761.

(20) Chen, S. Y.; Cheng, S. Stud. Surf. Sci. Catal. 2005, 156, 89. as cosolvent. Typically, $0.20-0.60 \mathrm{~g}$ of P123 $\left((\mathrm{EO})_{20}(\mathrm{PO})_{70}(\mathrm{EO})_{20}\right.$, Aldrich, $M_{\mathrm{n}}=5800$ ) and $0.59 \mathrm{~g}$ of $\mathrm{NaCl}$ (Acros, 99\%) were dissolved in $40 \mathrm{~g}$ of deionized water at $35^{\circ} \mathrm{C}$, and the solution was stirred for $2 \mathrm{~h}$, followed by the addition of $2.10 \mathrm{~g}$ of TEOS (Acros, 98\%). The mixture was sealed in a polypropylene (PP) bottle and stirred for $24 \mathrm{~h}$ and then hydrothermally treated in the static condition at $90{ }^{\circ} \mathrm{C}$ for another $24 \mathrm{~h}$. The solid precipitate was separated by filtering, washing with a $500 \mathrm{~mL}$ of deionized water, and drying at $50{ }^{\circ} \mathrm{C}$ overnight. Calcination of the samples was performed at $500{ }^{\circ} \mathrm{C}$ in air for $12 \mathrm{~h}$ with the ramp rate of $1{ }^{\circ} \mathrm{C}$ $/ \mathrm{min}$. The molar ratios of the reactants in the synthesis gel were 0.0034-0.0103:0.50-5.0:1:221 P123/ NaCl/TEOS/ $\mathrm{H}_{2} \mathrm{O}$. In other words, the concentrations of $\mathrm{P} 123$ and $\mathrm{NaCl}$ were varied in the range of $0.5-1.5 \mathrm{wt} \%$ and $0.13-1.27 \mathrm{M}$, respectively, in the synthesis gel. To study the effect of cosolvent, alcohol, such as absolute methanol, ethanol, and 1-propanol, was also added in the synthesis solution. The reactant compositions including ethanol were varied in the molar ratio of $0.0086: 1: 1: 221: 10.8-64.7 \mathrm{P} 123 / \mathrm{NaCl} /$ TEOS $/ \mathrm{H}_{2} \mathrm{O} / \mathrm{EtOH}$. The molar yields of silica materials based on the residues of TG analyses were around $86-93 \%$ without alcohols and $85-90 \%$ with alcohols.

Hydrothermal Stability. To examine the hydrothermal stability of the synthesized materials, about $0.30 \mathrm{~g}$ of calcined sample dispersed in $50 \mathrm{~mL}$ of deionized water was sealed in a PP bottle and heated at $100{ }^{\circ} \mathrm{C}$ under the static condition for $72 \mathrm{~h}$. The solid was then filtered and dried at $50{ }^{\circ} \mathrm{C}$ overnight.

Characterization. XRD patterns were recorded using a Philip $\mathrm{X}$ 'pert Pro diffractometer with $\mathrm{Cu} \mathrm{K} \alpha$ radiation operated at $40 \mathrm{~mA}$ and $45 \mathrm{kV}$. The pore structures of mesoporous silica materials were analyzed by nitrogen physisorption at liquid nitrogen temperature (77 K) using a Micrometerics TriStar 3000 system. Prior to the experiments, the materials were degassed at $200{ }^{\circ} \mathrm{C}$ for $6-8 \mathrm{~h}$ under vacuum $\left(10^{-3}\right.$ Torr). The specific surface areas were evaluated using the Brunauer-Emmett-Teller (BET) method in the $P / P_{0}$ range of 0.05-0.3. Pore size distribution (PSD) curves were calculated using the desorption branch of the isotherms and the Barrett-JoynerHalenda (BJH) method, ${ }^{21}$ and pore sizes were obtained from the peak positions of the distribution curves. The pore volume was accumulated up to $P / P_{0}=0.990$. The PSD of MCF was analyzed by using a modified BdB-FHH method with spherical pore model. ${ }^{7 \mathrm{a}}$

The SEM photographs were taken on a Hitachi S-800 field emission scanning electron microscope. The energy dispersed X-ray (EDX) emission spectra were taken with a Hitachi S-2400 scanning electron microscope. Sample preparation was similar to that for SEM experiment except the sample was stuck on the holder made by carbon instead of copper and without coating a gold-palladium alloy layer. The EDX data were the average result of more than 20 spots. The TEM was performed using a Hitachi H-7100 transmission electron microscope operating at $75 \mathrm{kV}$. The resin solidified samples cut into thin slices of 90-110 nm thickness were used for TEM studies. TG analyses were carried out on a Dupont TA 951 instrument with a ramping rate of $10{ }^{\circ} \mathrm{C} / \mathrm{min}$ in an air flow of 50 $\mathrm{mL} / \mathrm{min}$. The inductively coupled plasma-atomic emission spectroscopy (ICP-AES) spectra of the samples dissolved in mixed HF$\mathrm{HNO}_{3}$ solutions were taken using an ELAN 5000 instrument. The solid state ${ }^{29} \mathrm{Si}$ MAS NMR spectra were measured using a Bruker MSL-300 spectrometer with $7 \mathrm{~mm}$ zirconia rotors spun at $5 \mathrm{kHz}$. Data were acquired at $59.6 \mathrm{MHz}, 20 \mu \mathrm{s}$ pulse width, and $60 \mathrm{~s}$ recycle delay. The $\mathrm{Q}_{4} /\left(\mathrm{Q}_{2}+\mathrm{Q}_{3}\right)$ area ratios were obtained by deconvolution of the peaks in the spectra using WinFit software. Chemical shifts were externally referenced to trimethylsilane. The

(21) Barrett, E. P.; Joyner, L. G.; Hanlenda, P. C. J. Am. Chem. Soc. 1951, 73,373 . 

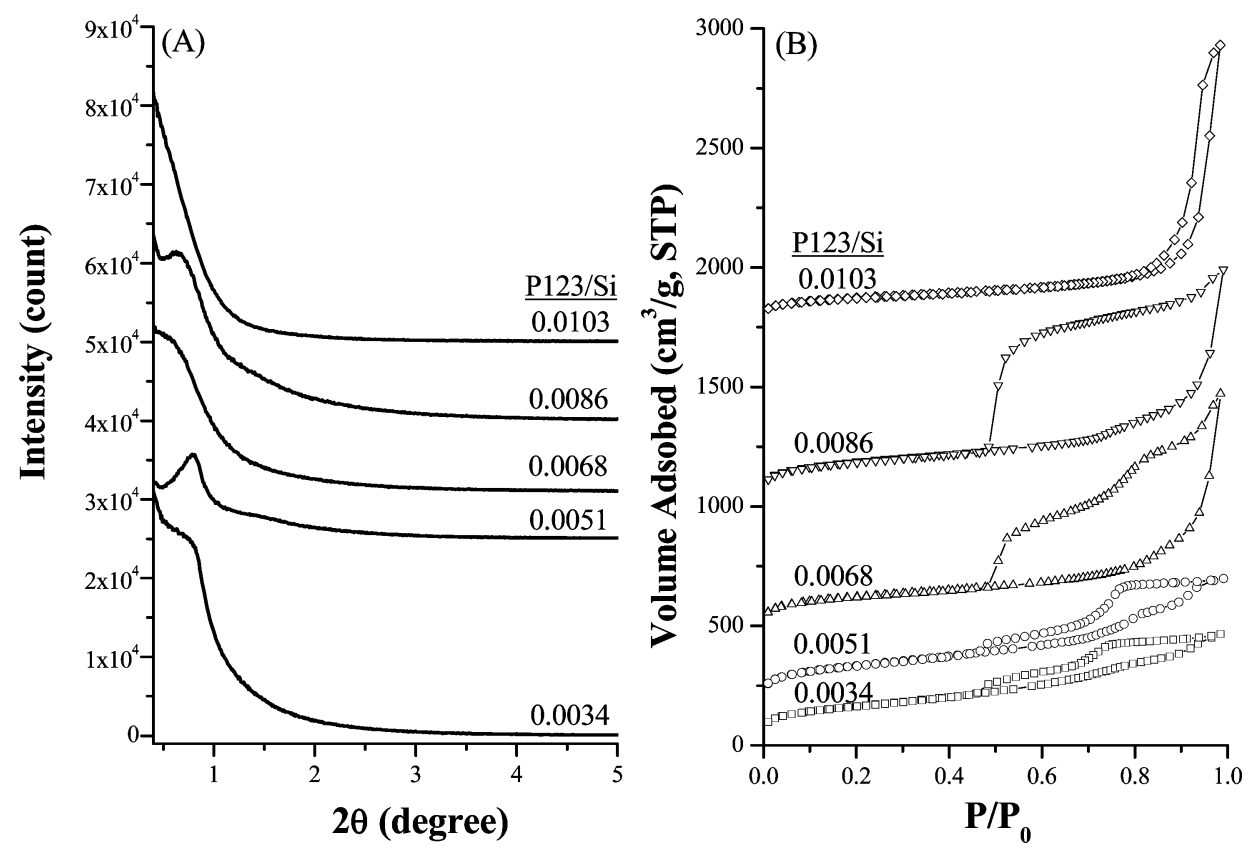

Figure 1. (A) Small-angle XRD patterns and (B) $\mathrm{N}_{2}$ adsorption-desorption isotherms of mesocellular silica foams synthesized in an acid-free $0.0034-$ 0.0103: 1:1:221 P123/NaCl/Si/ $\mathrm{H}_{2} \mathrm{O}$ system.

$\zeta$ potential of the P123 solution was measured by using a Malvern Zetasizer 3000 HS instrument.

\section{Results and Discussion}

The addition of proper concentrations of $\mathrm{NaCl}$ salt and P123 pore-directing agent was found to be essential to obtain silica materials of ordered mesostructures in acid-free conditions. Figure 1a shows the small-angle XRD patterns of calcined mesoporous silica materials prepared without adding hazardous mineral acids. When the $\mathrm{NaCl} / \mathrm{Si}$ molar ratio was around 1 , a broad diffraction peak around $2 \theta \sim 1^{\circ}$ was seen for the samples prepared with the reactant molar composition varied in $0.0034-0.0086: 1: 221 \mathrm{P} 123 / \mathrm{Si} / \mathrm{H}_{2} \mathrm{O}$. These results indicate that mesoporous silica materials with slightly ordered pore structures could be prepared in acid-free conditions when the reactant compositions are in the range of 0.00340.0086:1:1:221 P123/NaCl/TEOS/ $\mathrm{H}_{2} \mathrm{O}$.

Elemental analysis by either ICP-AES or the EDX technique shows that only a trace amount of sodium ions was left in the solid material $(\mathrm{Na} / \mathrm{Si}$ molar ratio $<0.003)$. The quantities of chloride ions measured by EDX were also negligible. These results revealed that both sodium and chloride ions were hardly incorporated into the silica mesostructure during the self-assembly of P123 micelles and silica precursors. It has been shown that the presence of nonadsorbed ions, such as chloride ions, in the solution would render the hydrophobic portion of the surfactant toward the more hydrophobic, so-called salting-out property. ${ }^{13,17-20}$ Moreover, the condensation and hydrolysis of silica have been found to increase by adding electrolytes in the synthesis solution. In the present study, similar effect was also observed with other salts including $\mathrm{NaBr}, \mathrm{NaSCN}$, tetramethylammonium chloride (TMACl), tetrapropylammnium bromide (TPABr), tetrabutylammonium bromide (TBABr), and benzyltrimethylammonium chloride (BTMACl).
The nitrogen sorption isotherms of calcined mesoporous silica materials are shown in Figure 1b. The adsorptiondesorption hysteresis loops were found to vary with the concentrations of $\mathrm{NaCl}$ salt and $\mathrm{P} 123$ copolymer in the mother solution. Most of the hysteresis loops covered a wide range of $P / P_{0}$ between 0.5 and 1.0 , indicating that pores from mesoporous to ultra-large sizes are probably present in the materials. ${ }^{7}$ For the applications in adsorption and catalysis where the diffusion of molecules was concerned, porous materials containing both macro- and mesoporous structures were reported to be better than those with only one kind of pore structure. .,22 $^{2}$

The amount of nitrogen adsorbed in the capillary condensation region seems to increase with the P123/Si molar ratios. For the materials prepared with a $\mathrm{P} 123 / \mathrm{Si}$ ratio within 0.0034-0.0051, the hysteresis loops were small in adsorbed volume but covered a wide $P / P_{0}$ range, indicating that the pore structures were complicated. When the P123/Si ratios were raised to $0.0068-0.0086$, the hysteresis loops expanded; the adsorption branches shifted to higher $P / P_{0}$ values whereas the desorption branches retained in similar $P / P_{0}$ region. Further increase in the $\mathrm{P} 123 / \mathrm{Si}$ ratio shifted both the adsorption and desorption branches of the isotherm to the very high $P / P_{0}$ region. According to the analyses by Karkamkar and co-workers ${ }^{18}$ who studied the change of hysteresis loops in mesocellular silica foam during the hydrothermal process, the materials prepared with $\mathrm{P} 123 / \mathrm{Si}$ ratios within $0.0068-0.0086$ correspond to an MCF-containing closed window cells while that prepared with $\mathrm{P} 123 / \mathrm{Si}$ ratio of 0.0103 is a MCF-containing open window cell. The cell and window diameters were calculated on the basis of the adsorption and desorption branches of the loops, respec-

(22) (a) Gagea, B. C.; Liang, D.; Tendeloo, G. V.; Martens, J. A.; Jacobs, P. A. Stud. Surf. Sci. Catal. 2006, 162, 259. (b) Yuan, Z. Y.; Ren, T. Z.; Azioune, A.; Pireaux, J. J.; Su, B. L. Chem. Mater. 2006, 18, 1753. 
Table 1. Structural Properties of Mesocellular Silica Foams

Synthesized under Acid-Free Conditions with Reactant Compositions within 0.0034-0.0103:1:1:221 P123/NaCl/Si/ $\mathrm{H}_{2} \mathrm{O}$

\begin{tabular}{ccccccccc}
\hline $\begin{array}{c}\mathrm{P} 123 / \mathrm{Si} \\
(\mathrm{molar} \\
\text { ratio })\end{array}$ & $\begin{array}{c}\mathrm{pH} \\
(\mathrm{gel})\end{array}$ & $\begin{array}{c}d \\
(\mathrm{~nm})\end{array}$ & $\begin{array}{c}S_{\mathrm{BET}} \\
\left(\mathrm{m}^{2} / \mathrm{g}\right)\end{array}$ & $\begin{array}{c}S_{\text {micro }} \\
\left(\mathrm{m}^{2} / \mathrm{g}\right)\end{array}$ & $\begin{array}{c}V_{\text {total }} \\
\left(\mathrm{cm}^{3} / \mathrm{g}\right)\end{array}$ & $\begin{array}{c}V_{\text {micro }} \\
\left(\mathrm{cm}^{3} / \mathrm{g}\right)\end{array}$ & $\begin{array}{c}D_{\mathrm{c}}{ }^{a} \\
(\mathrm{~nm})\end{array}$ & $\begin{array}{c}D_{\mathrm{w}}{ }^{a} \\
(\mathrm{~nm})\end{array}$ \\
\hline 0.0103 & 4.40 & 11.1 & 436 & 141 & 1.2 & 0.06 & 66 & 30 \\
0.0086 & 4.43 & 11.1 & 758 & 185 & 1.2 & 0.08 & 76 & 5 \\
0.0068 & 4.46 & 13.8 & 595 & 189 & 1.0 & 0.04 & 63 & 5 \\
0.0051 & 4.58 & 13.6 & 649 & 134 & 0.8 & 0.04 & 31 & 6 \\
0.0034 & 4.99 & n.d. & 580 & 110 & 0.7 & 0.03 & 27 & 5
\end{tabular}

${ }^{a}$ The diameters of cell $\left(D_{\mathrm{c}}\right)$ and window $\left(D_{\mathrm{w}}\right)$ determined from the adsorption and desorption branches, respectively, by using a modified BdBFHH method with a spherical model.

tively. The differences between the cell width $(63-76 \mathrm{~nm})$ and window diameter $(5-6 \mathrm{~nm})$ are greater for the closed window cells but smaller (66 and $30 \mathrm{~nm}$, respectively) for the open window cells. The expansion of the cell and window diameters was also observed by increasing the $\mathrm{NaCl}$ concentration in the synthesis solution when the P123/Si ratio was fixed at 0.0086 . These results show that silica materials with mesocellular pore structures can be prepared in aqueous solutions of $\mathrm{NaCl}$ salt and $\mathrm{P} 123$ copolymer without adding hazardous mineral acids and swelling agent.

The textural properties of the mesocellular silica materials are summarized in Table 1. For the sample synthesized with low P123/Si molar ratio of 0.0034 , the surface area and pore volume were $580 \mathrm{~m}^{2} / \mathrm{g}$ and $0.7 \mathrm{~cm}^{3} / \mathrm{g}$, respectively, which were slightly lower than those of SBA-15 synthesized in a strong acidic condition. ${ }^{6}$ When the P123/Si molar ratios were within $0.0051-0.0086$, the pore volume enlarged to $0.8-$ $1.2 \mathrm{~cm}^{3} / \mathrm{g}$, and the surface areas were within $595-758 \mathrm{~m}^{2} /$ $\mathrm{g}$, which were close to those of SBA-15 but slightly greater than those of MCF materials synthesized using TMB as swelling agents in strong acidic conditions. ${ }^{7}$ When the P123/ Si ratio was further raised to 0.0103 , the pore volume was retained around $1.2 \mathrm{~cm}^{3} / \mathrm{g}$. However, the surface area decreased to $436 \mathrm{~m}^{2} / \mathrm{g}$. It is noticeable that the sizes of the window and cell in the present MCF materials were larger than those synthesized under acidic conditions in previous reports. ${ }^{6-11}$ It suggests that the average aggregation number of P123 molecules in a micelle in the neutral brine is probably larger than that in the acidic solution. Recently, Song and co-workers ${ }^{12}$ also reported that the pore size of SBA-15 synthesized from neutralizing the acidic synthesis solution with a weak base was slightly greater than that from a strong acidic environment $(2 \mathrm{M} \mathrm{HCl})$. The micropore surface area and volume of the present MCF materials are around $110-185 \mathrm{~m}^{2} / \mathrm{g}$ and $0.04-0.08 \mathrm{~cm}^{3} / \mathrm{g}$, slightly lower than that of SBA-15 $\left(S_{\text {micro }}=168-200 \mathrm{~m}^{2} / \mathrm{g}\right.$ and $V_{\text {micro }}=$ $\left.0.06-0.12 \mathrm{~cm}^{3} / \mathrm{g}\right)^{6}$

The morphologies of mesocellular silica materials synthesized with $\mathrm{NaCl} / \mathrm{Si} \sim 1$ and various $\mathrm{P} 123$ concentrations were examined by SEM, and the photographs are shown in Figure 2. The silica materials are aggregates of spherical particles. The particle sizes seem to decrease with the increase of P123/Si molar ratio. Figure 2b,c shows that some pores of 50-250 $\mathrm{nm}$ in diameter can be seen in the cross sections of the broken particles prepared with a $\mathrm{P} 123 / \mathrm{Si}$ molar ratio of 0.0051 and smaller pores of $50-100 \mathrm{~nm}$ in diameter on those prepared with $\mathrm{P} 123 / \mathrm{Si}$ ratio of 0.0068 .
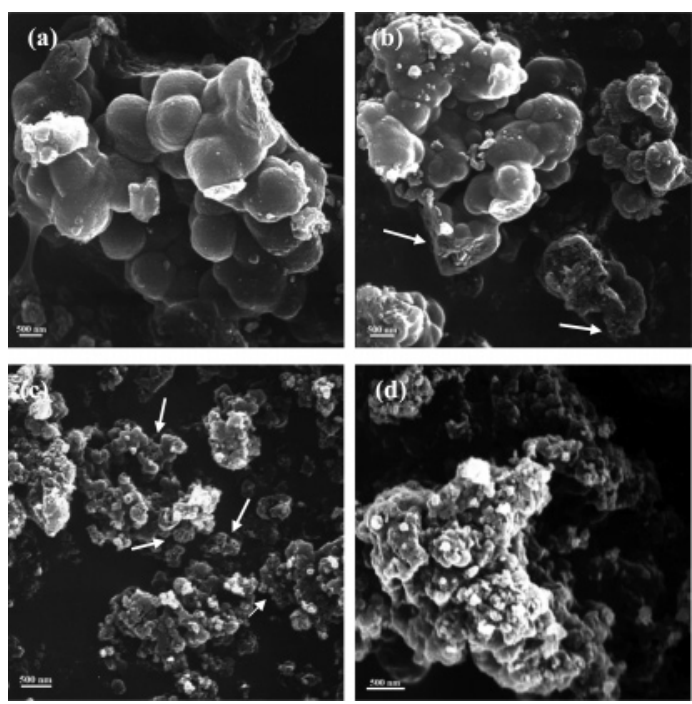

Figure 2. SEM photographs of mesocellular silica foams synthesized with a $\mathrm{NaCl} / \mathrm{Si}$ ratio of 1 and various P123/Si ratios of (a) 0.0034 , (b) 0.0051 , (c) 0.0068 , and (d) 0.0103 .

For the material prepared with $\mathrm{P} 123 / \mathrm{Si}$ ratio of 0.0103 , the pore structures are hardly seen because of the very small particle size (Figure 2d).

The pore structures of the MCF materials synthesized with $\mathrm{NaCl} / \mathrm{Si} \sim 1$ and various $\mathrm{P} 123$ concentrations were examined by TEM microscopy. Figure 3 shows that the threedimensional MCFs of diameter ranging in $50-200 \mathrm{~nm}$ can be clearly seen. Moreover, the walls of the foams synthesized with low P123/Si molar ratios in 0.0034-0.0051 contain nanopores of approximately $5-10 \mathrm{~nm}$ in diameter, which is consistent with the result of modified BdB-FHH pore size analysis. On the other hand, the mesocellular silica synthesized with P123/Si ratios greater than 0.0068 contain solidframework foams of approximately $50-100 \mathrm{~nm}$ in diameter and without nanopores on the walls (Figure $3 b$ ). When the P123/Si ratio was increased to 0.0103 , the walls of the foams seem to break into nanoslices with approximately 15-30 $\mathrm{nm}$ openings (Figure $3 \mathrm{c}$ ). These results on porous structures are consistent with the variation observed in nitrogen sorption hysteresis loops and the SEM photographs. The wall thickness of present MCF materials, based on the TEM photographs, is around $8-10 \mathrm{~nm}$ and much thicker than those of SBA-15 $\left(W_{\mathrm{t}}=3-4 \mathrm{~nm}\right)$ and MCF $\left(W_{\mathrm{t}}=4-6 \mathrm{~nm}\right)$ synthesized in acidic conditions reported in the literature. ${ }^{6 a}, 7 \mathrm{f}$

The interaction between the P-123 triblock copolymer and the framework of MCF materials was examined by the thermal analysis technique, and the results are compared with that of SBA-15 synthesized in $2 \mathrm{M} \mathrm{HCl}$ (Supporting Information). All the MCF materials showed a single-step weight loss at $185-195{ }^{\circ} \mathrm{C}$. Moreover, the weight losses varied in 27-44 wt \% are generally proportional to the concentration of P123 in the synthesis solutions. On the other hand, the weight loss due to decomposition of pore directing agent P123 in SBA-15 was 53 wt \% with the maximum differential thermogravimetric (DTG) temperature at $194{ }^{\circ} \mathrm{C}$. The similarity in decomposition temperatures of poredirecting agent P123 indicates that the interaction between P123 and the silica framework of MCF materials is similar in strength to that in SBA-15. It also implies that the triblock 


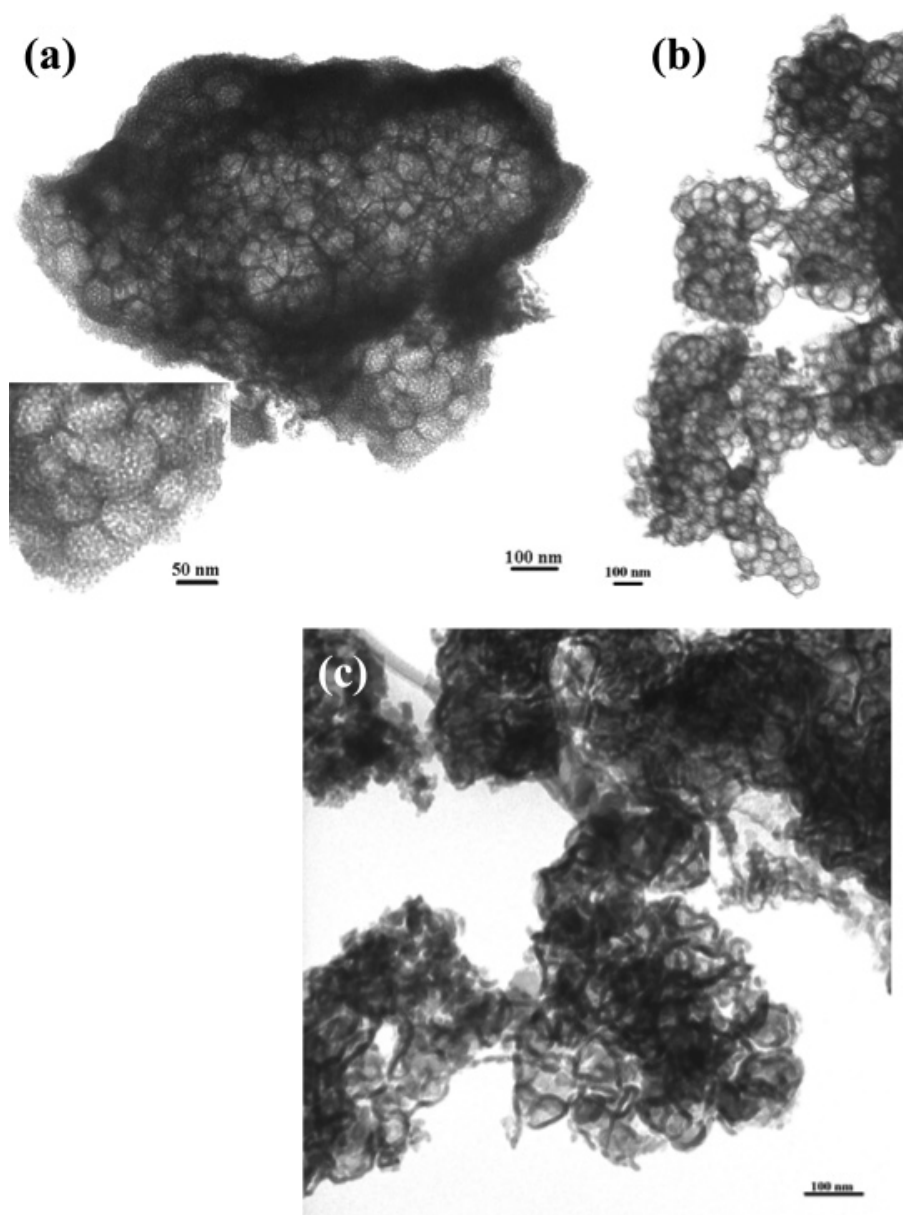

Figure 3. TEM photographs of mesocellular silica foams synthesized with a NaCl/Si ratio of 1 and various P123/Si ratios of (a) 0.0051 , (b) 0.0068 , and (c) 0.0103 , respectively.

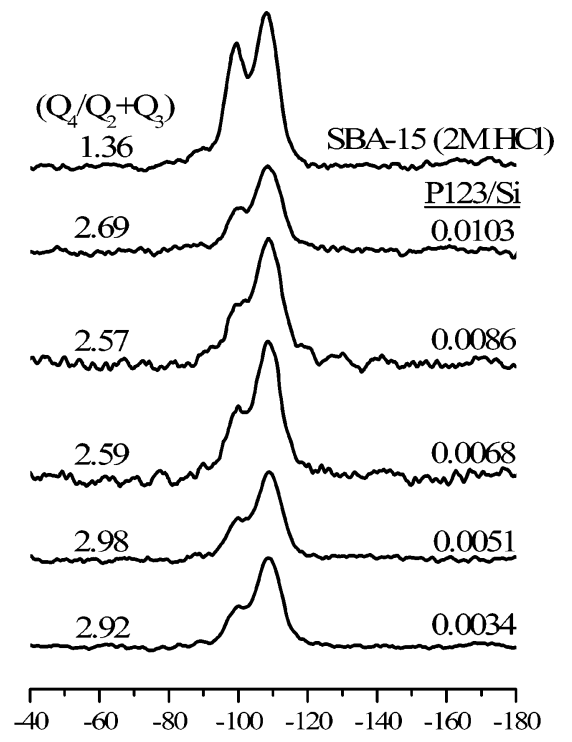

\section{Chemical Shift (ppm)}

Figure 4. Solid state ${ }^{29} \mathrm{Si}$ MAS NMR of as-made siliceous SBA-15 mesoporous material synthesized in the $2 \mathrm{M} \mathrm{HCl}$ system and mesocellular silica foams synthesized in an acid-free 0.0034-0.0103:1:1:221 P123/NaCl/ $\mathrm{Si} / \mathrm{H}_{2} \mathrm{O}$ system.

copolymer P123 is incorporated into the mesocellular silica foams through the self-assembly process.

Figure 4 shows the solid state ${ }^{29} \mathrm{Si}$ MAS NMR spectra of as-made MCF synthesized in acid-free conditions, in comparison to that of conventional SBA-15. Three peaks with chemical shifts at $-91,-99$, and $-108 \mathrm{ppm}$ are assigned to the $\mathrm{Q}_{2}, \mathrm{Q}_{3}$, and $\mathrm{Q}_{4}$ bands of $\mathrm{Si}(\mathrm{OH})_{2}(\mathrm{OSi})_{2}, \mathrm{Si}(\mathrm{OH})(\mathrm{OSi})_{3}$, and $\mathrm{Si}(\mathrm{OSi})_{4}$ silicate species, respectively. ${ }^{23}$ The $\mathrm{Q}_{4} /\left(\mathrm{Q}_{2}+\right.$ $\mathrm{Q}_{3}$ ) area ratios obtained by deconvolution of the spectra are also shown in Figure 4 . The $\mathrm{Q}_{4} /\left(\mathrm{Q}_{2}+\mathrm{Q}_{3}\right)$ value of as-made SBA-15 in the present study is 1.36 , similar to that of 1.28 reported in the literature. ${ }^{6}$ On the other hand, Schmidt-Winkel et al. ${ }^{7 f}$ have shown that the $\mathrm{Q}_{4} / \mathrm{Q}_{3}$ ratio of MCF prepared in $2 \mathrm{M} \mathrm{HCl}$ was around 2.22. The $\mathrm{Q}_{4} / \mathrm{Q}_{3}$ ratio increased to 2.50 when $\mathrm{NH}_{4} \mathrm{~F}$ was also applied in the synthesis. Comparatively, the $\mathrm{Q}_{4} /\left(\mathrm{Q}_{2}+\mathrm{Q}_{3}\right)$ values of $2.57-2.98$ obtained on the present mesocellular silica materials are much higher. It reveals that the silanol condensation is more complete under the acidfree synthesis condition. The $\mathrm{Q}_{4} /\left(\mathrm{Q}_{2}+\mathrm{Q}_{3}\right)$ values of mesoporous silica materials synthesized by basic and acidic routes are very distinct. The $\mathrm{Q}_{4} /\left(\mathrm{Q}_{2}+\mathrm{Q}_{3}\right)$ ratios were in 2.2-2.5 for MCM-41 synthesized at a $\mathrm{pH}$ around 10, and the ratios are much higher than those of conventional SBA15 synthesized in a strong acidic environment. ${ }^{6,23}$ However, the main factor which enhances the silanol condensation in this study is probably the presence of salt instead of the $\mathrm{pH}$ values of the synthesis solutions, which were within 4.4-5. Wang and co-workers ${ }^{23 a}$ have shown that the $\mathrm{Q}_{4} /\left(\mathrm{Q}_{2}+\mathrm{Q}_{3}\right)$

(23) (a) Wang, X.; Lin, K. S. K.; Chan, J. C. C.; Cheng, S. J. Phys. Chem. B 2005, 109, 1763. (b) Wouters, B. H.; Chen, T.; Dewilde, M.; Grobet, P. J. Microporous Mesoporous Mater. 2001, 44-45, 453. (c) Luhmer, M.; d'Espinose, J. B.; Hommel, H.; Legrand, A. P. Magn. Reson. Imaging 1996, 14, 911. 

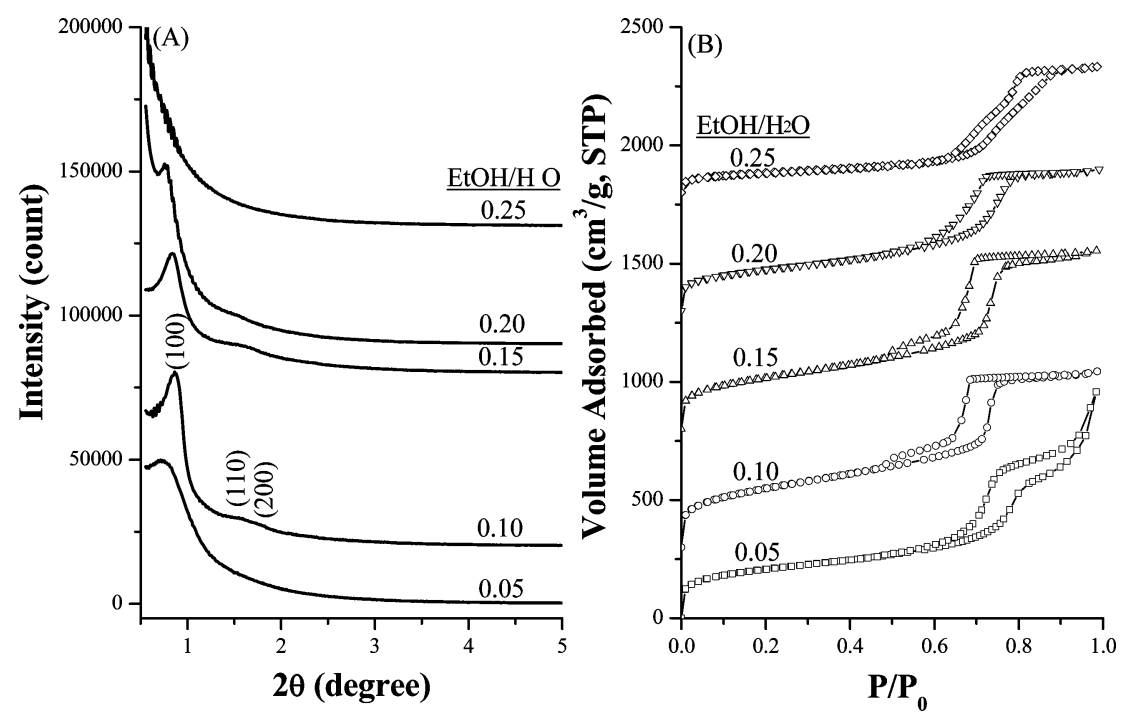

Figure 5. (A) Small-angle XRD patterns and (B) $\mathrm{N}_{2}$ adsorption-desorption isotherms of ordered mesoporous silica materials synthesized with various $\mathrm{EtOH} / \mathrm{H}_{2} \mathrm{O}$ ratios of $0.05-0.20$.

Table 2. Textual Properties of Ordered Mesoporous Silica Materials Synthesized with EtOH/ $\mathrm{H}_{2} \mathrm{O}$ Ratios in $0.05-0.25$

\begin{tabular}{|c|c|c|c|c|c|c|c|c|c|c|}
\hline $\begin{array}{c}\mathrm{EtOH} / \mathrm{H}_{2} \mathrm{O} \\
\text { (molar ratio) }\end{array}$ & $\begin{array}{l}\mathrm{pH} \\
\text { (gel) }\end{array}$ & $\begin{array}{l}d_{(100)} \\
(\mathrm{nm})\end{array}$ & $\begin{array}{c}a_{0} \\
(\mathrm{~nm})\end{array}$ & $\begin{array}{c}S_{\mathrm{BET}} \\
\left(\mathrm{m}^{2} / \mathrm{g}\right)\end{array}$ & $\begin{array}{l}S_{\text {micro }} \\
\left(\mathrm{m}^{2} / \mathrm{g}\right)\end{array}$ & $\begin{array}{c}V_{\text {total }} \\
\left(\mathrm{cm}^{3} / \mathrm{g}\right)\end{array}$ & $\begin{array}{c}V_{\text {mirco }} \\
\left(\mathrm{cm}^{3} / \mathrm{g}\right)\end{array}$ & $\begin{array}{c}D_{\mathrm{p}}{ }^{a} \\
(\mathrm{~nm})\end{array}$ & $\begin{array}{c}W_{\mathrm{t}}^{b} \\
(\mathrm{~nm})\end{array}$ & $\begin{array}{l}\mathrm{PSD}^{c} \\
(\mathrm{~nm})\end{array}$ \\
\hline 0.05 & 4.54 & 12.0 & 13.8 & 728 & 178 & 1.2 & 0.08 & 7.0 & 6.8 & 5.0 \\
\hline 0.10 & 4.59 & 10.5 & 12.1 & 896 & 81 & 1.1 & 0.03 & 6.3 & 5.8 & 2.5 \\
\hline 0.15 & 4.73 & 10.4 & 12.0 & 776 & 74 & 1.2 & 0.03 & 6.5 & 5.5 & 3.0 \\
\hline 0.20 & 4.82 & 11.7 & 13.5 & 626 & 85 & 0.9 & 0.03 & 6.6 & 6.9 & 4.8 \\
\hline 0.25 & 5.13 & n.d. & n.d. & 299 & 46 & 0.8 & 0.02 & 6.0 & n.d & 5.0 \\
\hline
\end{tabular}

${ }^{a}$ The peak positions of the distribution curves by BJH. ${ }^{b}$ Wall thickness. ${ }^{c}$ The peak width at half-maximum height of the BJH peak.

ratio of propylamine-functionalized SBA-15 prepared in 2 $\mathrm{M} \mathrm{HCl}$ with the aid of $\mathrm{NaCl}$ was around 2.2 and much higher than that of conventional SBA-15.

By adding a proper amount of alcohols, such as methanol, ethanol, and 1-propanol, as cosolvent into the acid-free synthesis gel of TEOS, $\mathrm{P} 123$, and $\mathrm{NaCl}$, mesoporous silica materials possessing ordered pore arrangement were obtained. The $\mathrm{pH}$ values of the synthesis gels did not vary significantly as alcohols were present. The small-angle XRD patterns of mesoporous silica materials synthesized with reactant compositions of 0.008:1:1:221:10.8-64.7 P123/ $\mathrm{NaCl} / \mathrm{TEOS} / \mathrm{H}_{2} \mathrm{O} / \mathrm{EtOH}$ are shown in Figure 5a. A strong diffraction peak at $2 \theta$ around $0.86^{\circ}$ and two weak peaks at 1.56 and $1.75^{\circ}$ were observed when the $\mathrm{EtOH} / \mathrm{H}_{2} \mathrm{O}$ molar ratios were in the range of $0.10-0.20$. The diffraction peaks were more intense and well-resolved than those of mesocellular silica foams prepared without EtOH as cosolvent. The locations of diffraction peaks are consistent with 2Dhexagonal $p 6 \mathrm{~mm}$ structure, similar to that of SBA-15 material. Comparatively, the $d$-spacings of these mesoporous silica materials are slightly smaller than those of MCF. It implies that the aggregation number of P123 in micelles probably decreased when ethanol was added in the synthesis solution. When the EtOH/ $\mathrm{H}_{2} \mathrm{O}$ molar ratios were out of $0.10-0.20$, only one broad diffraction peak or no peak was observed in the XRD patterns. The results indicate that mesoporous silica materials with fairly ordered $p 6 \mathrm{~mm}$ pore arrangement can be synthesized with the reactant compositions of $0.008: 1: 1: 221: 21.6-43.1 \mathrm{P} 123 / \mathrm{NaCl} / \mathrm{TEOS} / \mathrm{H}_{2} \mathrm{O} /$ $\mathrm{EtOH}$. Moreover, similar results were observed when $\mathrm{NaCl}$ was replaced by other salts or ethanol was replaced by methanol or propanol.

The nitrogen sorption isotherms of the mesoporous silica materials synthesized with EtOH as cosolvent are shown in Figure 5b. With EtOH/ $\mathrm{H}_{2} \mathrm{O}$ molar ratio in $0.05-0.25$, the silica materials show type IV isotherms with $\mathrm{H}_{1}$ hysteresis loops, very similar to that of SBA-15 prepared in $2 \mathrm{M} \mathrm{HCl}^{6}$ The corresponding textural properties are summarized in Table 2. All the materials prepared with EtOH as cosolvent, except the one with EtOH/ $\mathrm{H}_{2} \mathrm{O}$ ratio as high as 0.25 , have relatively high surface areas $\left(626-896 \mathrm{~m}^{2} / \mathrm{g}\right)$, mesopores of $6.3-7.0 \mathrm{~nm}$ in diameter, and large pore volumes $(0.9-1.2$ $\mathrm{cm}^{3} / \mathrm{g}$ ). It is also noticeable that the shape of the hysteresis loops varied slightly with the amount of ethanol added in the synthesis gel. The steepest hysteresis loops were observed at $P / P_{0}$ between 0.6 and 0.75 for the material synthesized with a EtOH/ $\mathrm{H}_{2} \mathrm{O}$ molar ratio within $0.10-0.15$, implying that the PSDs for these samples are relatively narrow. The PSD values determined from the peak widths at halfmaximum of the BJH PSD profiles were $2.5-3.0 \mathrm{~nm}$ (Table 2 ), which are similar to that of SBA-15. However, a small quantity of smaller mesopores of approximately $3.7 \mathrm{~nm}$ in diameter was also observed on these materials. These pores are likely attributed to the defects formed in the structure.

The TG and DTG analyses of ordered mesoporous silica materials synthesized under acid-free condition with a P123/ Si molar ratio kept at 0.0086 and $\mathrm{EtOH} / \mathrm{H}_{2} \mathrm{O}$ ratios within $0.05-0.25$ are compared with those of SBA- 15 synthesized with $2 \mathrm{M} \mathrm{HCl}$, and the profiles are shown in Figure 6. The decomposition of pore directing agent P123 was found to 


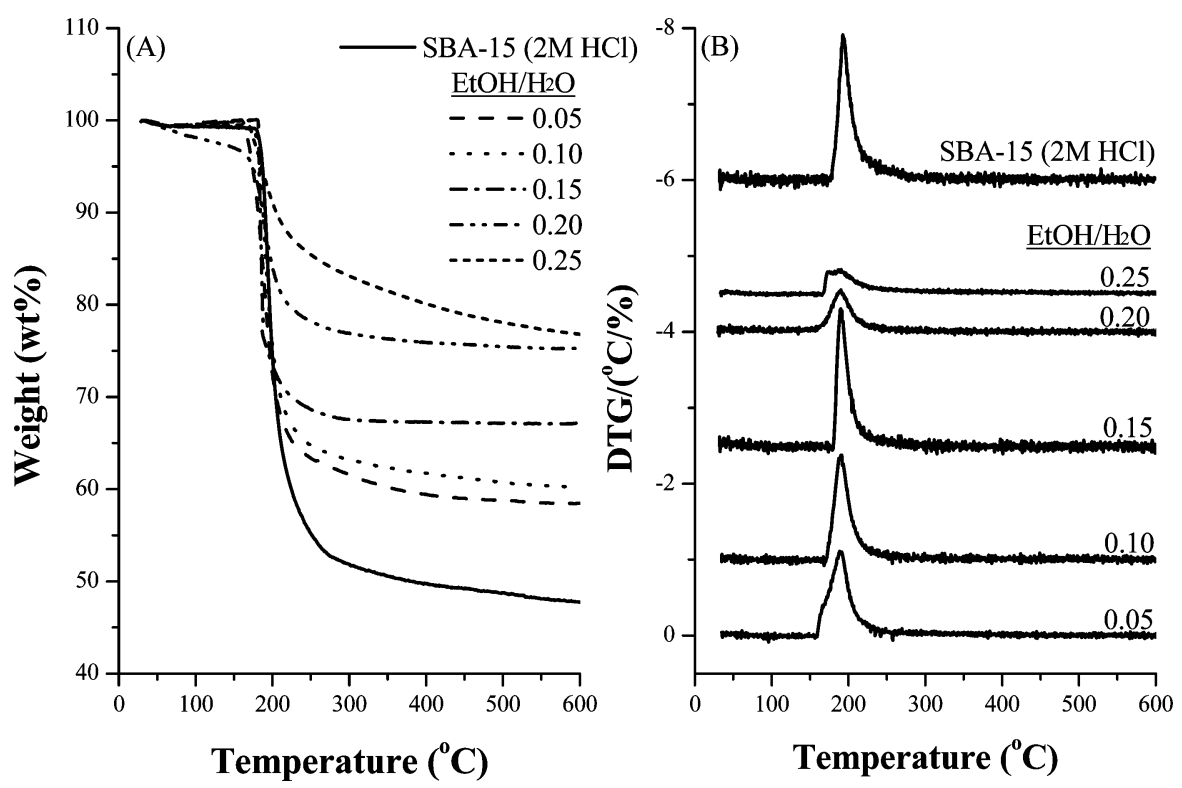

Figure 6. (A) TG analysis and (B) DTG profiles of ordered mesoporous silica materials synthesized with various EtOH/ $\mathrm{H}_{2} \mathrm{O}$ ratios of $0.05-0.20$.

occur around $190^{\circ} \mathrm{C}$. It implies that the interactions between the pore directing agent P123 and the silica framework in these mesoporous silica materials are similar. Because the $\mathrm{pH}$ values of the synthesis solutions in the present study were within 4.4-5.1, which were independent of the presence of ethanol or not, silicate should remain negatively charged. The isoelectric point of a $5.8 \mathrm{wt} \%$ P123 aqueous solution was determined to be around 6.1 (Supporting Information). Hence, the P123 micelles should be partially protonated in the synthesis solutions with $\mathrm{pH}$ within 4.4-5. Therefore, the self-assembly of P123 and silica is proposed to proceed through a weakly electrostatic force or hydrogen bonding. The weight losses due to the decomposition of P123 in the ordered mesoporous silica materials were within $24-42 \mathrm{wt}$ $\%$, less than that of SBA-15. Moreover, the weight loss decreased as the amount of ethanol added in the synthesis solution increased. Because better ordering of the pore structures was observed in the presence of alcohol, alcohol should help the self-assembly of P123 micelles and silicate species. It has been proposed that alcohols probably change the volume ratio of poly(ethylene oxide) (PEO)/poly(propylene oxide) (PPO) and P123 micelles of uniform sizes are formed in the solutions containing alcohols as cosolvent. ${ }^{17,24-27}$ However, no weight losses corresponding to the desorption or decomposition of ethanol were detected in the TG profiles, possibly due to the easy vaporization of alcohols during the drying process.

The TEM photographs of mesoporous silica materials synthesized in acid-free conditions with the $\mathrm{EtOH} / \mathrm{H}_{2} \mathrm{O}$ molar ratios in the range of $0.05-0.25$ are shown in Figure 7. For the material prepared with EtOH/ $\mathrm{H}_{2} \mathrm{O}$ ratio smaller than 0.05 , most of the structures are MCFs. When the EtOH/ $\mathrm{H}_{2} \mathrm{O}$ ratio is raised to $0.1-0.2$, the ordered hexagonal pore arrangement

(24) Lin, H. P.; Mou, C. Y. Acc. Chem. Res. 2002, 35, 927.

(25) Kim, T.-W.; Kleitz, F.; Paul, B.; Ryoo, R. J. Am. Chem. Soc. 2005, 127,7601 .

(26) Wang, Y.; Wang, Y.; Yang, C.-M.; Lu, G.; Schuth, F. Langmuir 2006, $22,5491$.

(27) Tang, J. W.; Yu, C. Z.; Zhou, X. F.; Zhao, D. Y. Chem. Commun. 2004, 2240. and well-aligned nanochannels can be clearly seen in the cross section of the particles. The diameter of the nanochannels is about $5-6 \mathrm{~nm}$, slightly smaller than that estimated by BJH pore size analysis. Although a small quantity of worm-like and vesicular pores are also seen, to the best of our knowledge, this is the first report on the synthesis of pure silica material with ordered hexagonal mesopores using triblock copolymer template under acid-free conditions. The vesicular structures have also been observed in the gelled state of M41S material. ${ }^{28}$ The formation of vesicular structures was suggested to be due to the strong absorption of ions, such as silicate oligomers and counteranions, or swelling agent on the surfactant micelles. On the basis of the TEM results, the aggregation number of P123 in micelles in the brine is probably decreased when ethanol is present as cosolvent, as a result of the variation in the polarity of the solvent.

The solid state ${ }^{29} \mathrm{Si}$ MAS NMR spectra of as-made mesoporous silica materials synthesized with ethanol as cosolvent under acid-free conditions are shown in Figure 8. Similar to the MCF silica prepared without ethanol, the degree of silicate condensation in the mesoporous silica materials synthesized with ethanol is more complete than that of SBA-15. However, the $\mathrm{Q}_{4} /\left(\mathrm{Q}_{2}+\mathrm{Q}_{3}\right)$ values in the range of 1.80-2.39 are lower than those of MCF silica prepared without ethanol. Moreover, the $\mathrm{Q}_{4} /\left(\mathrm{Q}_{2}+\mathrm{Q}_{3}\right)$ value decreases with the increase in ethanol concentration in the synthesis solution, implying that ethanol may disturb the silanol condensation.

The structure and ordering of triblock copolymer micelles in aqueous solution have been found to change with the electrolytes, cosolvents, and swelling agents.,13-20,23-27 Recently, Kim and co-workers ${ }^{25}$ found that the introduction of butanol to the synthesis gel of silica with triblock copolymer as pore-directing agent could tune the mesostructure efficiently. Butanol has been proposed to locate

(28) Pevzner, S.; Regev, O.; Lind, A.; Linden, M. J. Am. Chem. Soc. 2003, 125,652 . 


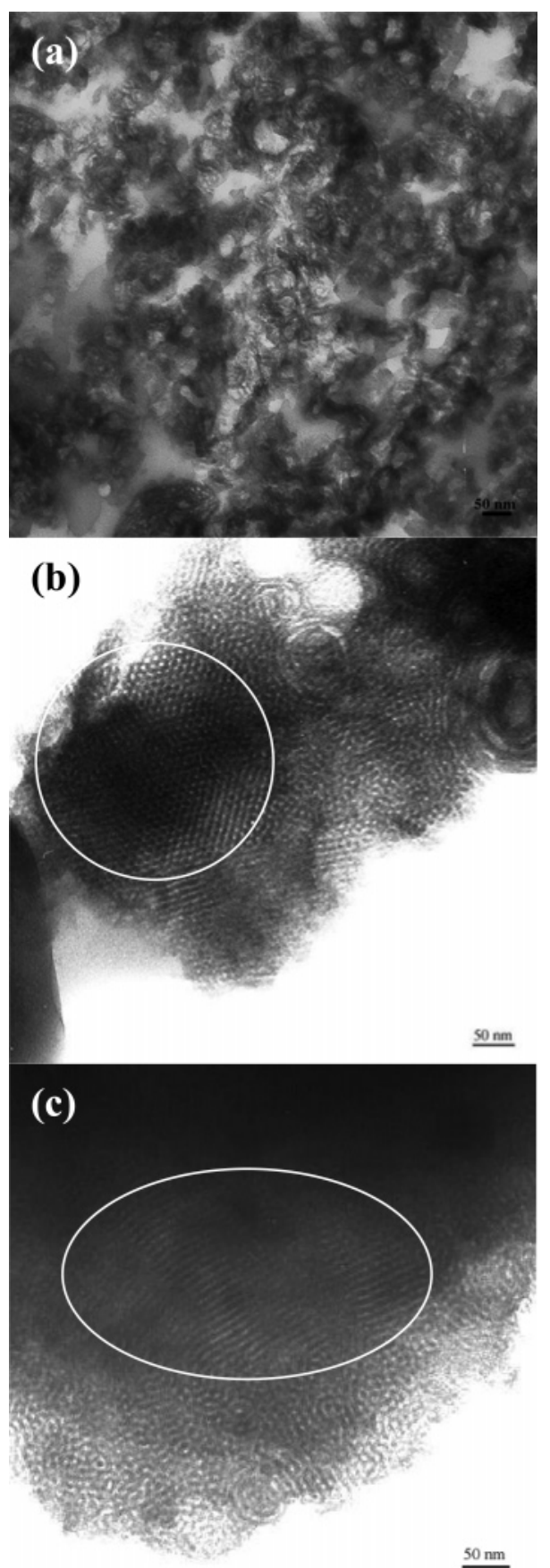

Figure 7. TEM photographs of ordered mesoporous silica materials synthesized with $\mathrm{EtOH} / \mathrm{H}_{2} \mathrm{O}$ ratios of (a) 0.05 and (b, c) 0.10 .

mainly at the hydrophilic-hydrophobic interface of PEO and PPO blocks, stabilize the micellar aggregates, and determine the surface curvature of the micelles. In the present study, alcohols probably have similar effect. On the other hand, the appearance of white precipitate in the present acid-free conditions was found to slow down when ethanol was present as the cosolvent. It implies that alcohols can change the polarity of synthesis solutions and reduce the hydrolysis and condensation rates of silicate species.

To investigate the formation mechanism of mesoporous silica material with ordered hexagonal pores, the gels before and after hydrothermal treatment (HT) for different periods were collected. The XRD patterns and $\mathrm{N}_{2}$ sorption isotherms of calcined mesoporous silica are shown in Figure 9. A broad

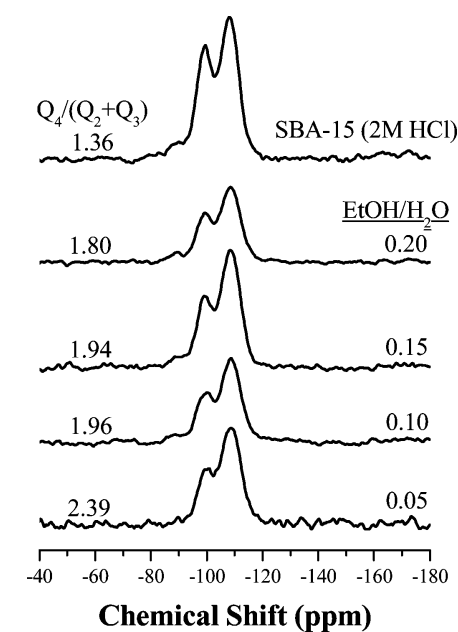

Figure 8. Solid state ${ }^{29} \mathrm{Si}$ MAS NMR of as-made siliceous SBA-15 mesoporous material synthesized in a $2 \mathrm{M} \mathrm{HCl}$ system and ordered mesoporous silica materials synthesized with various $\mathrm{EtOH} / \mathrm{H}_{2} \mathrm{O}$ ratios of $0.05-0.20$.

XRD peak at $2 \theta \sim 1^{\circ}$ is seen on the material before HT. As the HT period lengthened, the peak becomes sharper and shifted slightly toward the low-angle region, and another diffraction peak grows gradually at $1.3-2.0^{\circ}$. These results indicate that the ordering of mesoporous structure is improved under HT. The corresponding $\mathrm{N}_{2}$ sorption isotherms show consistent variation. The type IV isotherm with a weak hysteresis loop covering a wide $P / P_{0}$ region was found on the material before HT, and it transformed gradually toward a sharp hysteresis loop covering a narrower $P / P_{0}$ region as HT prolonged. These results indicate that the arrangement of mesopores becomes more ordered accompanied by the pore size narrowing when the HT period is lengthened. On the other hand, the hysteresis loop extended to the high $P / P_{0}$ region (around $0.85-0.90$ ) for the materials before HT is probably attributed to the porous texture from the aggregated particles in sub-micrometer sizes. This high-pressure loop becomes less pronounced as the HT is prolonged and disappears after the material is hydrothermally treated for $24 \mathrm{~h}$. A similar phenomenon has also been reported by Han and Ying ${ }^{29}$ who studied mixed surfactant system containing fluorocarbon cationic surfactant and amphiphilic triblock copolymer. The adsorption step in the high $P / P_{0}$ region has also been attributed to the inter-particle porosity.

The SEM and TEM photographs of the mesoporous silica materials synthesized with ethanol as cosolvent after various HT periods are displayed in Figure 10. Small particles with a size less than $100 \mathrm{~nm}$ are observed for the material before HT. Its TEM photograph shows aggregates of nanosized particles and mainly inter-particle pores as well as wormlike or tubular-like pore structure in the silica particles. After $\mathrm{HT}$ for $12 \mathrm{~h}$, the material forms large particles with diameter greater than $1 \mu \mathrm{m}$, which are however the aggregates of small particles and therefore look loose. In its TEM photograph, worm-like pore structures with pore diameter around $4 \mathrm{~nm}$ arranged in slightly ordered patterns can be found in a relatively large domain. After HT for $24 \mathrm{~h}$, solid particles with smooth surface were obtained. The TEM photograph

(29) Han, Y.; Ying, J. Y. Angew. Chem., Int. Ed. 2005, 44, 288. 

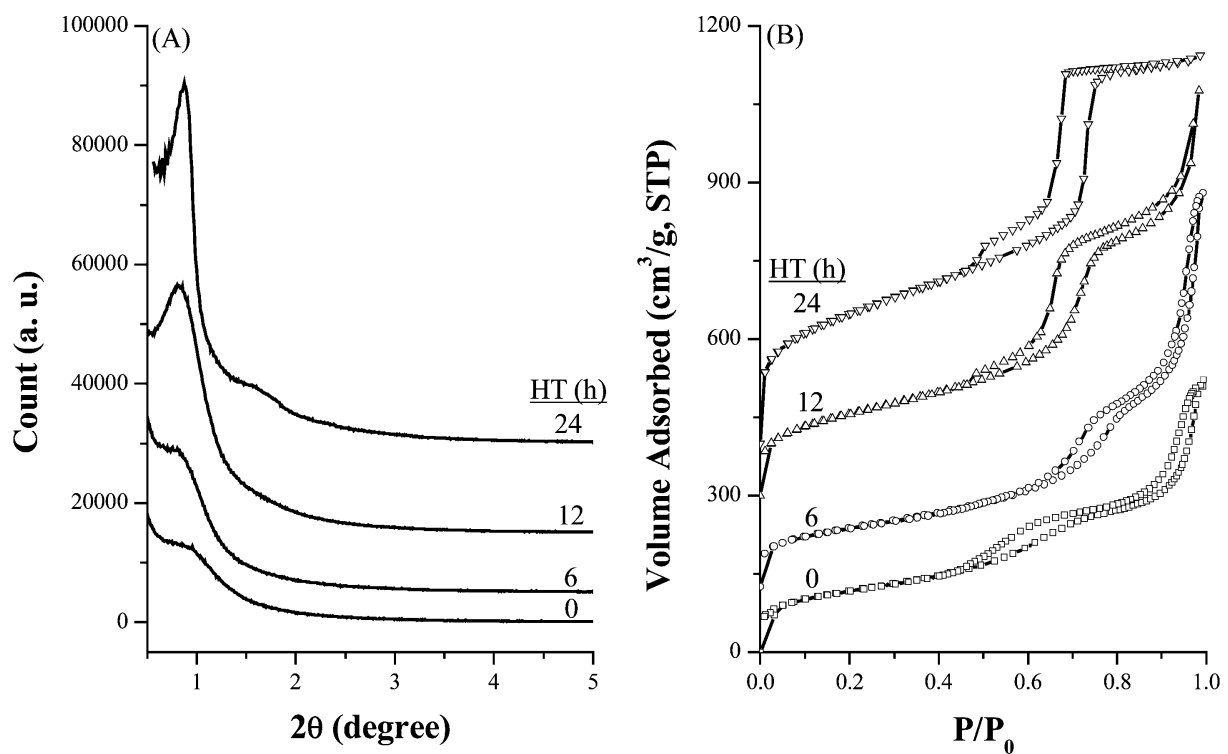

Figure 9. (A) Small-angle XRD patterns and (B) $\mathrm{N}_{2}$ adsorption-desorption isotherms of ordered mesoporous silica materials synthesized with a EtOH/ $\mathrm{H}_{2} \mathrm{O}$ ratio of 0.1 and varied hours of $\mathrm{HT}$.
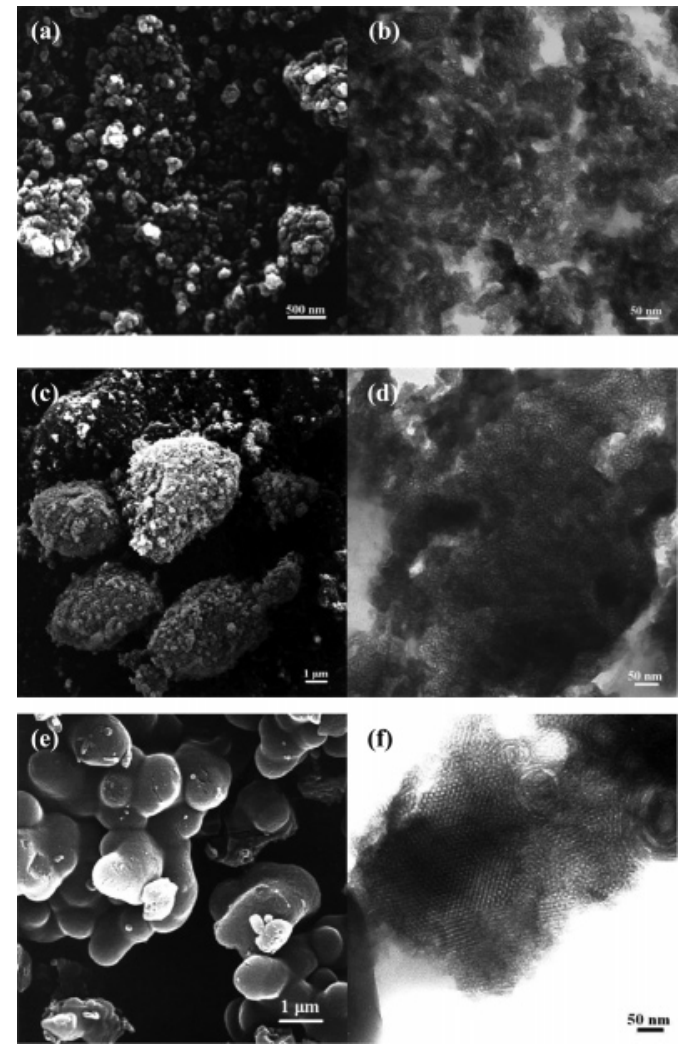

Figure 10. SEM and TEM photographs of mesoporous silica materials prepared with HT of (a, b) $0 \mathrm{~h}$; (c, d) $12 \mathrm{~h}$; and (e, f) $24 \mathrm{~h}$.

reveals that the material contains mesopores of hexagonalordered arrangement and the pore size has been expanded to 5-6 nm. These results are well consistent with those of $\mathrm{N}_{2}$ sorption isotherms. The P123 micelles in the neutral salt solution containing approximately $10 \mathrm{~mol} \%$ ethanol are probably in short cylindrical or elliptic shape of approximately $4 \mathrm{~nm}$ in diameter. The silicate condensated around the micelles forms worm-like pores before HT. The HT seems to expand the micelles and enhance the silicate condensation and results in silica materials containing
Table 3. Hydrothermal Stability of MCF Materials after Boiling in Water for $72 \mathrm{~h}$

\begin{tabular}{cccccrc}
\hline $\begin{array}{c}\text { P123/Si } \\
\text { (molar ratio })\end{array}$ & $\begin{array}{c}S_{\text {BET }} \\
\left(\mathrm{m}^{2} / \mathrm{g}\right)\end{array}$ & $\begin{array}{c}S_{\text {micro }} \\
\left(\mathrm{m}^{2} / \mathrm{g}\right)\end{array}$ & $\begin{array}{c}V_{\text {total }} \\
\left(\mathrm{cm}^{3} / \mathrm{g}\right)\end{array}$ & $\begin{array}{c}V_{\text {micro }} \\
\left(\mathrm{cm}^{3} / \mathrm{g}\right)\end{array}$ & $\begin{array}{c}D_{\mathrm{c}}{ }^{a} \\
(\mathrm{~nm})\end{array}$ & $\begin{array}{c}D_{\mathrm{w}}{ }^{a} \\
(\mathrm{~nm})\end{array}$ \\
\hline 0.0103 & 266 & 45 & 2.08 & 0.019 & 68 & 42 \\
0.0086 & 462 & 88 & 1.56 & 0.038 & 93 & 76 \\
0.0068 & 407 & 96 & 1.77 & 0.043 & 78 & 11 \\
0.0051 & 415 & 65 & 1.08 & 0.027 & 125 & 25 \\
0.0034 & 422 & 63 & 0.79 & 0.027 & 90 & 19
\end{tabular}

${ }^{a}$ The diameters of cell $\left(D_{\mathrm{c}}\right)$ and window $\left(D_{\mathrm{w}}\right)$ determined from the adsorption and desorption branches, respectively, by using a modified BdBFHH method with a spherical model.

hexagonal-arranged mesopores of 5-6 $\mathrm{nm}$ in diameter, similar to those of SBA-15 and MSU-H materials.

In the literature, it has been reported that ethanol has good solubility toward both PEO and PPO groups. ${ }^{30,31}$ Addition of ethanol in aqueous solution has great influence on the self-assembly of block copolymer, such as the increase in CMT and the decrease in the aggregation number of block copolymer in the micelle. Ganguly and co-workers ${ }^{30}$ have shown that the size of prolate ellipsoid P123 micelles in the aqueous solution containing $10 \mathrm{wt} \%$ of P123 was reduced by adding ethanol. The core radius of P123 micelles in the presence of $10 \mathrm{wt} \%$ ethanol has also been estimated to be approximately $5 \mathrm{~nm}$, which is close to the pore diameter of the ordered mesoporous silica material synthesized in the present study.

The hydrothermal stabilities of the ultra-large MCF and hexagonal-arranged mesoporous silica materials prepared in acid-free conditions were tested by boiling in $100{ }^{\circ} \mathrm{C}$ water for $72 \mathrm{~h}$. No detectable changes in the pore structures were seen on the TEM photographs (Supporting Information). The XRD patterns of MCF show that only the samples synthesized with a P123/Si ratio within $0.0034-0.0051$ still display a weak diffraction peak at $2 \theta \sim 0.75^{\circ}$ after boiling in water

(30) Ganguly, R.; Aswal, V. K.; Hassan, P. A.; Gopalakrishnan, I. K.; Yakhmi, J. V. J. Phys. Chem. B 2005, 109, 5653.

(31) Soni, S. S.; Brotons, G.; Bellour, M.; Narayanan, T.; Gibaud, A. $J$. Phys. Chem. B 2006, 110, 15157. 

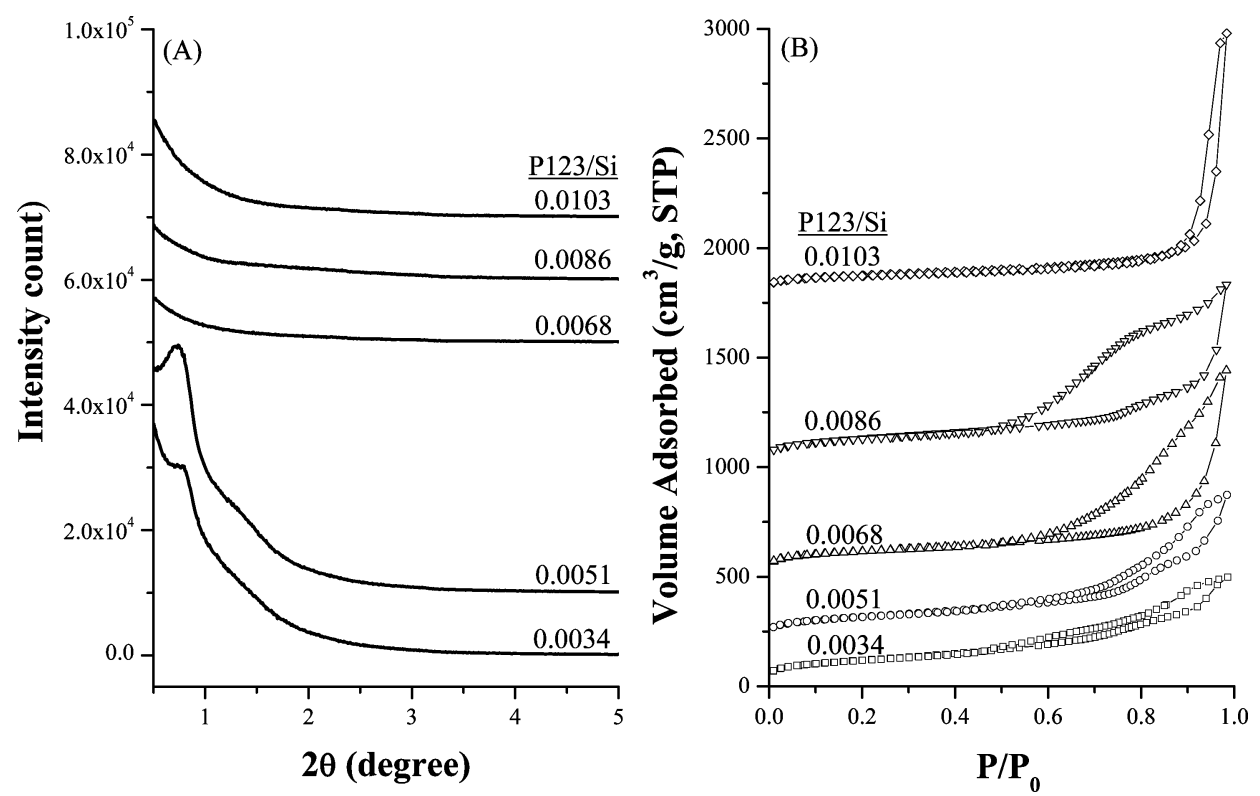

Figure 11. (A) Small-angle XRD patterns and (B) $\mathrm{N}_{2}$ sorption isotherms of mesocellular silica foams after boiling in water for $72 \mathrm{~h}$.
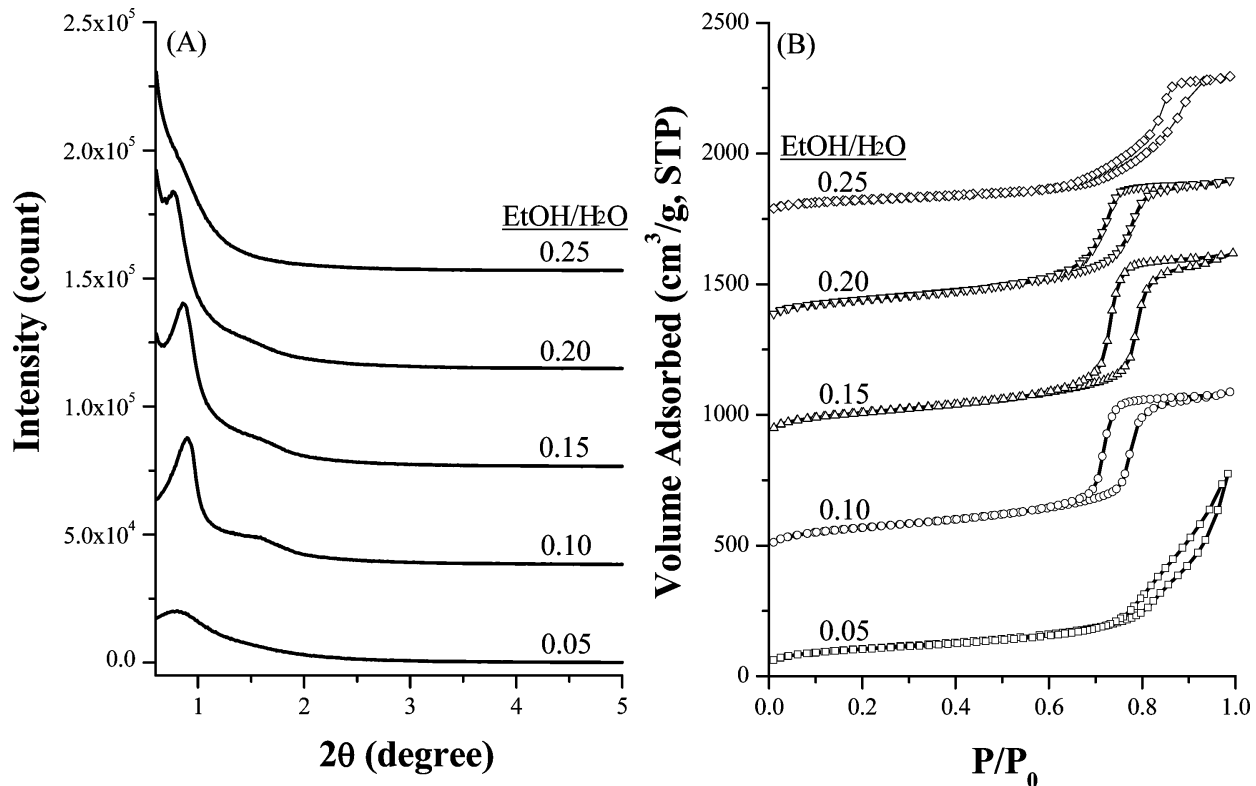

Figure 12. (A) Small-angle XRD patterns and (B) $\mathrm{N}_{2}$ sorption isotherms of mesoporous silica materials synthesized with the EtOH/ $\mathrm{H}_{2} \mathrm{O}$ ratios of $0.05-0.20$ and treated by boiling water for $72 \mathrm{~h}$.

Table 4. Hydrothermal Stability of Ordered Mesoporous Silica Materials Synthesized with Ethanol Cosolvent after Boiling in Water for $72 \mathrm{~h}$

\begin{tabular}{clcccccccc}
\hline $\begin{array}{c}\text { EtOH } / \mathrm{H}_{2} \mathrm{O} \\
(\mathrm{molar} \text { ratio })\end{array}$ & $d_{(100)}(\mathrm{nm})$ & $\begin{array}{c}S_{\mathrm{BET}} \\
\left(\mathrm{m}^{2} / \mathrm{g}\right)\end{array}$ & $\begin{array}{c}S_{\text {micro }} \\
\left(\mathrm{m}^{2} / \mathrm{g}\right)\end{array}$ & $\begin{array}{c}V_{\text {total }} \\
\left(\mathrm{cm}^{3} / \mathrm{g}\right)\end{array}$ & $\begin{array}{c}V_{\text {mirco }} \\
\left(\mathrm{cm}^{3} / \mathrm{g}\right)\end{array}$ & $\begin{array}{c}D_{\mathrm{p}}{ }^{a} \\
(\mathrm{~nm})\end{array}$ & $\begin{array}{c}W_{\mathrm{t}}^{b} \\
(\mathrm{~nm})\end{array}$ & $\begin{array}{c}\mathrm{PSD}^{c} \\
(\mathrm{~nm})\end{array}$ \\
\hline 0.05 & 11.0 & 372 & 57 & 0.98 & 0.024 & 9.0 & 2.0 & 2.0 \\
0.10 & 9.8 & 467 & 68 & 0.98 & 0.028 & 6.9 & 2.9 \\
0.15 & 10.2 & 478 & 68 & 1.1 & 0.028 & 7.4 & 2.8 \\
0.20 & 11.6 & 464 & 71 & 0.89 & 0.030 & 7.5 & 4.1 \\
0.25 & n.d. & 265 & 41 & 0.83 & 0.017 & 12.8 & 1.1 \\
n.d. & 9.6
\end{tabular}

${ }^{a}$ The peak positions of the distribution curves by BJH. ${ }^{b}$ Wall thickness. ${ }^{c}$ The peak width at half-maximum height of the BJH peak.

for $72 \mathrm{~h}$ (Figure 11a). The corresponding $\mathrm{N}_{2}$ sorption isotherms show that the desorption branches of the hysteresis loops shift toward higher $P / P_{0}$ region and the adsorbed volumes decrease (Figure 11b). This phenomenon is elucidated by that the nanopores in the silica framework of $\mathrm{MCF}$ disappear and the window of the foams is enlarged, as a result of further condensation of the silanol groups in the boiling water. Table 3 shows that the surface areas and pore volumes of the mesocellular silica foams after boiling in water are all reduced.

The small-angle XRD patterns and $\mathrm{N}_{2}$ sorption isotherms of the mesoporous materials synthesized with ethanol as cosolvent after boiling in water for $72 \mathrm{~h}$ are shown in Figure $12 \mathrm{a}, \mathrm{b}$, respectively. The XRD peaks remain well-resolved and intense, indicating that the ordered mesostructures were retained. Consistently, the $\mathrm{N}_{2}$ sorption isotherms still preserve 
the type IV isotherms with $\mathrm{H}_{1}$ hystersis loops. However, the loops shift slightly toward higher $P / P_{0}$ region. The BJH pore size analysis shows that the pore sizes are enlarged from $6.0-7.0 \mathrm{~nm}$ to $6.9-13 \mathrm{~nm}$ (Table 4). It is also noteworthy that the defect pores of approximately $3.7 \mathrm{~nm}$ in diameter observed in the original materials disappear. These results suggest that the silica framework around the defects probably re-constructs in boiling water. Accordingly, although the BET surface areas decrease from $600-900 \mathrm{~m}^{2} / \mathrm{g}$ to $460-480 \mathrm{~m}^{2} /$ $\mathrm{g}$, the pore sizes increase and the PSD narrows down from $2.5-3.0 \mathrm{~nm}$ to $1.0-1.7 \mathrm{~nm}$ for the materials synthesized with $\mathrm{EtOH} / \mathrm{H}_{2} \mathrm{O}$ molar ratio within $0.10-0.20$.

\section{Conclusions}

In the absence of hazardous acids or swelling agent, mesoporous silica materials with tunable pore structures including ultra-large mesocellular foam and ordered hexagonal pore arrangement were successfully synthesized using amphiphilic triblock copolymer as template with the aids of salt and alcohol. The pore structure of resultant materials could be finely controlled by varying the concentrations of triblock copolymer, salt, and cosolvent in the synthesis solution. The mesocellular silica foams with ultra-large cell size, closed window, and nanopores on the walls were obtained in a low P123/Si ratio of $0.0034-0.0051$ and $\mathrm{NaCl} /$ $\mathrm{Si}$ ratio around 1 . The porous network changed from a closed window foam to an open one when the P123/Si ratio was over 0.0103 or the $\mathrm{NaCl} / \mathrm{Si}$ ratio was raised to 2 . It is particularly noteworthy that mesoporous silica material with hexagonal-arranged pore structure, similar to that of SBA15 and MSU-H materials, could be made by adding 10-20 mol \% of alcohol in the synthesis solution. This is the first report on synthesis of large mesoporous silica material with ordered hexagonal-arranged pores in neutral conditions. The ordered mesoporous silica synthesized with alcohol as cosolvent was hydrothermally stable up to $72 \mathrm{~h}$. Moreover, as a result of the re-construction of the silica framework during HT, the materials had less defects and narrower PSD.

Acknowledgment. The financial support from the National Science Council and the Ministry of Education, Taiwan, is gratefully acknowledged. Acknowledgment is also extended to C.-Y. Tang and C.-Y. Lin of National Taiwan University for TEM and SEM experiments, C.-N. Ke of National Tsing-Hua University, Taiwan, for the ICP-AES experiment, and S.-Y. Sun of National Cheng Kung University, Taiwan, for the ${ }^{29} \mathrm{Si}$ MAS solid-state NMR experiment. S.-Y.C. would like to thank Prof. G. D. Stucky of University of California at Santa Barbara, U.S.A., and Dr. W. Lukens of Lawrence Berkeley National Laboratory, U.S.A., for the helpful discussion and for providing the modified BdB-FHH program to analyze the pore structure and PSD of mesocellular silica foams.

Supporting Information Available: TG and DTG profiles of MCF materials synthesized in acid-free conditions, $\zeta$ potential vs $\mathrm{pH}$ profile for a $\mathrm{P} 123$ aqueous solution, and TEM photographs (PDF). This material is available free of charge via the Internet at http://pubs.acs.org.

CM070232Y 